\title{
Linking Risk Attitudes, Time Preferences, and Body Mass Index in Catalonia
}

\begin{abstract}
Obesity is projected to increase in the coming years, despite the various socioeconomic policies implemented by governments and policy makers. As a result, some studies have suggested that obesity should be looked at from a psychological point of view, that is, individuals' propensity to become addicted to the consumption of fat-rich foods. Although previous studies have supported this, the results have been inconclusive: methodologically and geographically. This study uses a robust approach to elicit the risk and time preferences of food consumers. It goes further to ascertain the correlations between these parameters and obesity. Despite the methodological and geographical differences, our results support a strong relationship between body mass index and risk aversion, but not for loss aversion. In addition, time discounting significantly influences individuals’ propensity to increase body mass index.
\end{abstract}

Keywords: Prospect theory, Risk preferences, Time preferences; Body Mass Index, Catalonia

\section{Introduction}

The World Health Organization (WHO) considers obesity to be the most important cause of chronic illness and an epidemic in the 21st century, given its impact on morbidity, quality of life, and healthcare expenditure (WHO, 2016). People who are overweight or obese make up about 39\% and 23\% of the adult population in Spain (Gutiérrez-Fisac et al., 2012). People with obesity are at risk of heart attack and diabetes and show highly decreased levels of both productivity and life expectancy (Allison et al., 1999; Colditz, 1992). Economically, soaring obesity rates have led to a significant increase in both direct medical costs and the indirect costs resulting from lost productivity (McGinnis and Foege, 1993; Sturm, 2002; Wolf and Colditz, 1998).

Several socioeconomic factors have been found to play a major role in the high prevalence rate of obesity in Spain (Costa-Font and Gil, 2006). As a result, various socioeconomic policies have been targeted at obese people or people with a high risk of becoming obese. However, obesity is projected to increase in the coming years (OECD, 2017). As a result, 
1 some studies have suggested that obesity should be looked at from the context of individuals' 2 propensity to become addicted to the consumption of certain foods (Cawley, 1999).

3 Addiction to unhealthy behaviours, such as alcohol, drugs, and smoking, are usually 4 explained by the rational addiction model of Becker and Murphy (1988). From the rational 5 addiction context, obese individuals value the benefit from current consumption more than 6 the present value of future health implications that result from overeating. The study of the 7 interdependencies between the rate of time preferences, the coefficient of risk aversion, and 8 an addiction to unhealthy behaviours, such as smoking, drinking, and unhealthy eating, has become popular (Ida and Goto, 2009).

Therefore, researchers have hypothesized that higher time discount rates could explain why some people are more likely to have unhealthy diets and respond unsuccessfully to interventions aimed at encouraging dietary change (Leitch et al., 2013; Rollins et al., 2010). Impatient people may disregard the long-term effects of fat and sugar consumption and invest in less healhty foods rather than in nutrient-rich foods. Previous studies have found that the extent of time discounting varies considerably among persons (Fishburn and Rubinstein, 1982; Frederick et al., 2002; Thaler and Shefrin, 1981), tending to be higher among younger persons (Reimers et al., 2009; Steinberg et al., 2009), individuals with lower socioeconomic status (Reimers et al., 2009), less-educated persons (Jaroni et al., 2004; Lee et al., 2013), and those with a higher risk of obesity (McLaren, 2007).

Aside from time discounting, people's risk preferences (risk aversion and loss aversion) have a predominant effect on their consumption decisions. Past literature has shown that individuals' struggles to maintain a healthy diet might be due to the existence of the phenomenon of loss aversion in consumption decision making. Loss aversion strongly influences the tendency for people to base decisions on movements away from a current state rather than on the final outcome and to regard losses from that state more than gains (Kahneman et al., 1991; Tversky and Kahneman, 1992).

Psychological factors, such as risk and time preferences, have a major influence on how individuals make food choices. In summary, the literature supports that obese and overweight persons are less risk averse or more loss averse (Anderson and Mellor, 2008; de Oliveira et al., 2016; Davis et al., 2010) and exhibit higher time preference rates (Borghans and Golsteyn, 2006; Komlos et al., 2004; Smith et al., 2005). 
1 However, with the exception of de Oliveira et al. (2016), all studies mentioned above were 2 partial, in the sense that they only consider the relationship between risk attitudes or time 3 preferences of respondents with their body mass index. As in de Oliveira et al. (2016), the aim of this study is to jointly consider the role that risk and time preferences play in the tendency to become overweight and obese. Furthermore, this study tries to overcome some of the limitations of that study, namely: 1) as the focus was on people with low educational background, the visual multiple price list of Eckel and Grossman (2008) was used to elicit both risk and time preferences, which did not allow to account for subjects' attitudes toward losses, 2) their methodological framework was not flexible enough to estimate prospect theory parameters (risk aversion, loss aversion, and probability weighting), which has been proved to be very useful in behavioural economics, as we will show later, and 3) the method used to estimate the discount rate did not allow for differentiating whether subjects exhibit hyperbolic, quasi-hyperbolic or exponential time discounting behaviour.

To tackle these limitations, in this study we have adopted the incentivised double multiple price list (MPL) approach of Tanaka et al. (2010) as it allows estimating both prospect theory parameters (risk, loss aversion, and probability weighting) as well as time preference parameters (discount rate, present bias, and hyperbolicity) of consumers. This approach has been previously used in other domains to elicit both risk and time preferences such as Anderson and Mellor (2008) and Tanaka et al. (2010), to estimate risk and time preferences of the Danish adult population and Vietnamese rice farmers, respectively. However, this study constitutes, up to our knowledge, the first application on the consumers domain to investigate how risk and time preference parameters correlate with body mass index. To do that, two main tasks have been performed: 1 ) we have designed two lotteries to calculate risk and time preference parameters, 2) we have analyzed the impact of such parameters on participants' body mass index. In the latter, we have controlled for a variety of individual covariates, including marital status, education, age, and income, that have been shown in the literature to be common drivers of obesity.

The remainder of this article is structured as follows: section 2 provides a brief literature review on risk and time preferences. Section 3 discusses the sampling technique, experimental design, and the empirical methods used to derive our risk- and time-preference parameters. Section 4 presents and discusses the main results. The paper ends with some concluding remarks and limitations in section 5. 


\section{Conceptual framework and literature review}

\subsection{Risk preferences}

The expected utility (EU) theory has long been the standard approach in behavioural economics modelling. Based on this framework, several methods have been developed to estimate the concavity of the utility function, such as the Balloon Analogue Risk Task (BART), the Eckel and Grossman method, the Domain-Specific Risk-Taking (DOSPERT) scale, or the Multiple Price Lists, among the most relevant.

The Balloon Analogue Risk Task (BART) (Lejuez et al., 2002) presents subjects with a sequence of choices of whether or not to gain additional money by pumping more air into a balloon, with each pump coming with the risk of losing the accumulated gains if the balloon pops. BART has been used to study risk attitudes across a variety of subfields, such as neuroscience (Fecteau et al., 2007), drug addiction (Bornovalova et al., 2005), and psychopathology (Hunt et al., 2005), However, it is not clear if this method, initially designed for analysing financial risk behaviour could be extended to other domains. In addition, BART requires a computer and multiple implementation trials, making it time consuming and inapplicable when there are no computers.

In the Eckel and Grossman method (Eckel and Grossman, 2008), participants are presented with a number of gambling games and are asked to choose one that they would like to play. This method has been used by Reynaud and Couture (2012) and Dave et al. (2010). Even though this method produces significantly less noisy estimates of risk preferences, compared to BART, it does not allow the researcher to differentiate between different degrees of riskseeking behaviour.

The Domain-Specific Risk-Taking (DOSPERT) scale developed by Weber et al. (2002) elicitates risk parameters through a questionnaire. DOSPERT relies on the individual's selfreported propensity for risk. The scale contains 40 items: eight items in the domains of recreation, health, social, and ethical risks and four items in the domains of gambling and investment. DOSPERT has been applied by Hanoch et al. (2006) to elicit the domain-specific nature of risk preferences. Despite the simple nature of the DOSPERT method, Charness et al. (2013) argue that the elicited risk preferences may not reflect an individual's true attitudes toward risk in each domain since the technique is not incentivized. 
1 Holt and Laury (2002) popularized the use of the Multiple Price List lottery to estimate the concavity of the individual's utility function. The MPL has become very popular and has been widely used by researchers to compare risk attitudes across a wide array of contexts and environments (Anderson and Mellor, 2008). However, as in the previous methods based on the expected utility framework, it only allows researchers to estimate the concavity of the utility function.

Prospect theory (PT) (Kahneman and Tversky,1979) and the mental accounting framework (Thaler, 1980) have become very relevant in recent literature on behavioural economics (Harrison et al., 2010; Liu and Huang, 2013; Tanaka et al., 2010). PT postulates that risk preferences are not solely based on the concavity of the utility function but also on probability weighting and individuals' aversion to losses. Integration of loss aversion and probability weighing into individual preferences has enabled the prospect theory to explain a wide variety of economic phenomena that were considered puzzles from the expected utility point of view (Nguyen and Leung, 2009). Tanaka et al. (2010), following the Holt and Laury's Multiple Price List lottery, proposed the double Multiple Price List (MPL) lottery to allow for the estimation of the three prospect theory parameters: risk aversion, loss aversion, and probability weighting. They applied it to elicit the risk preferences of Vietnamese farmers, assuming a constant absolute risk aversion (CARA) utility function that was separable and stationary across time.

The double MPL was initially criticized on the basis that respondents might not understand the lottery, which could reduce the reliability of the results. In addition, participants might make inconsistent decisions by switching more than once. However, Anderson and Galinsky (2006) and Tanaka et al. (2010) dealt with these limitations by imposing strict monotonicity on revealed preferences and enforced transitivity. Several studies in the past have tried to establish a relationship between obesity and risk attitudes, such as de Oliveira et al. (2016), Borghans and Golsteyn (2006), Komlos et al. (2004), and Smith et al. (2005). However, none of these studies used the double MPL lottery, which is one of the main novelties of this study.

\subsection{Time Preferences}

Delay discounting can be defined as the extent to which people discount rewards (e.g. money, food, weight loss, etc.) as a function of having to wait for it (Reynolds et al., 2004). A low time discount rate indicates that an individual is patient and has self-control; on the contrary, a high time discount rate indicates that the individual is impatient and puts more emphasis on 
1 current gains over future rewards. Policies, especially fiscal policies, addressing obesity2 related problems and its determinants, are likely to be flawed if there is a strong relationship 3 between the rate of time preference and the propensity to become obese. Interventions need to factor these behavioural patterns into policy development and implementation.

Measurement approaches to discount rates vary due to: i) how surveys are administered; ii) the technique by which the discount rate is to be estimated; and (iii) whether rewards are real or hypothetical monetary choices. Surveys are usually administered in two ways: i) by questionnaire or ii) by a computerized method. Discount rates and present bias parameters are usually estimated by fitting an exponential discounting model (Kirby and Maraković, 1995; Myerson and Green, 1995), a hyperbolic model (Kahneman and Tversky, 1979; Mazur, 1987; Thaler and Shefrin, 1981), or a quasi-hyperbolic discount method (Benhabib et al., 2010). Hyperbolic and exponential discount models only measure the discount rate of money, while the quasi-hyperbolic discount model measures both the discount rate and present bias. The literature supports that exponential discounting performs poorly in the presence of experimental data (Frederick et al., 2002). As such, Laibson (1997) proposed a quasihyperbolic discounting model that performs better with field data. Moreover, previous literature supports that individuals are present bias and have high affinity toward high discount rates.

Tanaka et al. (2010) suggested a general time-preference model based on Benhabib et al's. (2010) experimental approach that is able to estimate three time-preference parameters: discount rates, present bias, and hyperbolicity. Moreover, their model also allows for comparing its performance in relation to the exponential, hyperbolic, and quasi-hyperbolic models mentioned above.

The literature also provides a few studies that have tried to relate time preferences to unhealthy behaviours (Appelhans et al., 2012; Leitch et al., 2013; Rollins et al., 2010), all of them supporting the existence of a strong relationship using different functional forms to estimate the discount parameter. This study is the first attempt to analyse the relationship between BMI and time preferences by adopting a flexible functional form, allowing us to jointly consider discount rates, present bias, and hyperbolicity. 


\section{Methodological framework}

\subsection{The sample}

Our sample comprised 180 respondents from the Metropolitan Area of Barcelona (Spain). The sample was stratified taking into account the 2012 distribution of the population by BMI and age from the National Health Survey. Survey participants signed a letter of confidentiality before the start of the experiment and were paid 30 euros for completing the survey. Each participant completed the entire questionnaire in an average of 60-75 minutes. Out of the 180 respondents who completed the questionnaire, seven submitted incomplete questionnaires and were, therefore, discarded. Each survey covered detailed information on individual characteristics and participants' choices for risk- and time-preferences games. Respondents were asked to state their body mass index, which was validated after the experiment. The weight and height of the respondents were validated by trained personnel using a calibrated digital scale and stadiometer, respectively. BMI was calculated using the standard formula: $\mathrm{kg} / \mathrm{m}^{2}$. Participants were categorized into three groups: underweight ${ }^{1}$ and normal weight group (<24.9); overweight group (25-29.9); and obesity group (>30.0) based on WHO criteria.

\subsection{Risk Preferences}

Under the PT, the individual's utility function can be expressed as follows:

$$
P T(x, y ; p)=p v(x)+(1-p) v(y)
$$

$$
\text { where } v(x)= \begin{cases}x^{\sigma} & \text { for } x \geq 0 \\ -\lambda\left(-x^{\sigma}\right) & \text { for } x<0\end{cases}
$$

$$
\text { and } w(p)=\exp \left[-(-\ln p)^{\gamma}\right]
$$

$P T(x, y ; p)$ is the expected prospect value over binary prospects consisting of the outcome $(x$, $y$ ) with the corresponding probability $(p, 1-p)$. In our experiment, $(x, y ; p)$ was specified for plan A and plan B in all scenarios. Note that the value function $v(x)$ should be estimated with $x^{\sigma}$ for $x>0$ or $-\lambda\left(-x^{\sigma}\right)$ for $x<0$. The parameter $\sigma$ represents the concavity of the value function (risk aversion) — high values indicate respondents are risk loving; $\lambda$ represents the degree of loss aversion—high values indicating respondents are more loss averse; and $\gamma$ is a proxy for the nonlinear probability weighting.

\footnotetext{
${ }^{1}$ The underweight and normal weight categories were combined due to the lower number of participants ( $2 \%$ of the sample) falling into the underweight category.
} 


\section{Experiment design}

To elicit the three PT parameters $(\sigma, \lambda$, and $\gamma)$, respondents were given three series of games that contained 35 pair-wise choices. Appendix A shows the three series of games. Series 1 consists of 14 games. Series 2 consists of 14 games, and Series 3 consists of seven games. In each game, the respondent is offered two plans: plan A and plan B. For instance, in series 1, the first game shows that plan A offers $30 \%$ chance of receiving 4 euros and $70 \%$ chance of receiving 1 euro, while plan B offers 10\% chance of receiving 6.8 euros and 90\% chance of receiving 0.5 euros. Since there are 14 games, each respondent has to decide whether he or she prefers plan A or plan B for each row ${ }^{2}$.

Following Tanaka et al. (2010), monotonicity was imposed on the respondents' choice decisions, indicating that if respondent $i$ switches at row $\mathrm{q}$ for series 1 , we conclude that he/she prefers plan A over plan B at row q-1 and prefers plan B over plan A at row q. Thus, each respondent had three options: a) choose plan A throughout all games; b) choose plan B throughout all games; and c) choose plan A for a certain number of games and then switch to plan B for the rest. Individuals who are more averse to loss would choose plan A a greater number of times over plan B. Series 2 followed the same procedure as in series 1 . The lossaversion parameter is calculated using series 3. Contrary to the previous two series, payoffs in this series were either positive or negative.

After the respondent completed the experiment, two bingo cages were used to determine the money that each respondent took home. The first bingo cage contained 35 numbered balls (indicating which row/question to play), while the second contained 10 numbered balls (indicating the probability). If ball number 10 was randomly selected from the first bingo cage, this meant that the subject would play row/question 10 out of the 35 questions. Once the question has been determined, a ball would be drawn from the 10 numbered balls in the second bingo and the selected question was played according to the subject's plan. For instance, if the subject drew the ball number 2 from the second bingo and had previously chosen plan A, he or she would have earned 4 Euro (or 0.5 Euro if the respondent had chosen plan B).

\section{Calculating risk parameters}

The switching points from series 1 and series 2 are used to estimate the curvature of the utility function (risk aversion) and the nonlinear probability-weighting parameter of each

\footnotetext{
${ }^{2}$ The maximum amount offered in Plan B was $170 €$, equivalent to the regulated minimum salary for one week.
} 
1 participant. Calculated parameter estimates ${ }^{3}$ of risk aversion and probability weighting for different combinations of the switching points in series 1 and series 2 are shown in Table 1 and Table 2, respectively. For instance, from Table 1, if the respondent switched at game 5 in series 1 and game 3 in series 2, then the corresponding risk aversion parameter is 1.0, indicating risk neutral. Also, for the probability-weighting parameter, if the respondent switched at game 5 in series 1 and game 3 in series 2, then the corresponding risk aversion parameter is 0.8 , indicating overweighting of low probabilities.

\section{Paste Table 1 here}

Paste Table 2 here

After obtaining the risk-aversion and probability-weighting parameters from both series 1 and series 2, we can estimate the loss-aversion parameter using the switching points in series 3. This was achieved by writing out an inequality for the switiching points of series 3 and introducing the risk parameter into the equation 1 (see Liu and Huang, 2013).

\subsection{Time preferences}

Following Benhabib et al. (2004) and Tanaka et al. (2010), we have estimated a general timepreference model that nested other models that have been traditionally used in the literature to elicit time preferences: exponential, hyperbolic, and quasi-hyperbolic discounting. Under the general framework, the present value of income, $y$, at time $t>0$ adopts the following expression:

$$
y \beta(1-(1-\theta) r t)^{1 /(1-\theta)}
$$

where $\mathrm{r}, \beta$, and $\theta$ are the time discounting, present bias, and hyperbolicity parameters of the time preference function. If $\beta=1$, as $\theta$ approaches 1 , then the discounted value of y reduces to exponential discounting $\left(e^{-r t}\right)$ in the limit. However, if $\beta=1$, when $\theta=2$, the discounted value reduces to a hyperbolic discounting model $(1 /(1+\mathrm{rt}))$. In the same way, if $\theta=1$ (in the limit) and $\beta$ is free, the discounted value reduces to a quasi-hyperbolic

\footnotetext{
${ }^{3}$ Example when a respondent switch from plan A to B at the fifth question in series 1 and at the third question in series 2, the following inequalities should hold. Average estimates are shown in Table 1 and Table 2. $4^{\sigma} \exp \left[-(-\ln .3)^{\alpha}\right]+1^{\sigma} \exp \left[-(-\ln .7)^{\alpha}\right]>9.3^{\sigma} \exp \left[-(-\ln .1)^{\alpha}\right]+0.5^{\sigma} \exp \left[-(-\ln .9)^{\alpha}\right]$, $4^{\sigma} \exp \left[-(-\ln .3)^{\alpha}\right]+1^{\sigma} \exp \left[-(-\ln .7)^{\alpha}\right]<10.6^{\sigma} \exp \left[-(-\ln .1)^{\alpha}\right]+0.5^{\sigma} \exp \left[-(-\ln .9)^{\alpha}\right]$, $4^{\sigma} \exp \left[-(-\ln .9)^{\alpha}\right]+3^{\sigma} \exp \left[-(-\ln .1)^{\alpha}\right]>5.6^{\sigma} \exp \left[-(-\ln .7)^{\alpha}\right]+0.5^{\sigma} \exp \left[-(-\ln .3)^{\alpha}\right]$, $4^{\sigma} \exp \left[-(-\ln .9)^{\alpha}\right]+3^{\sigma} \exp \left[-(-\ln .1)^{\alpha}\right]<5.8^{\sigma} \exp \left[-(-\ln .7)^{\alpha}\right]+0.5^{\sigma} \exp \left[-(-\ln .3)^{\alpha}\right]$.
} 
1 discounting model $\left(\beta e^{-r t}\right)$. These restrictions imposed on the general model allow us to

2 estimate and compare four time discounting models.

3 Experiment Design

4 The basic experimental design for eliciting individual discount rates and present bias follows 5 the approach of Tanaka et al. (2010). The experiment started by reading the following instruction to participants: "In this game, you will receive money either today or sometime in the future, depending on the choices you make. There are 75 games (Appendix B). In each game, we will offer you two plans: plan A or plan B. We would like you to choose either plan A or plan B for each question.” The experiment lasted about 35 minutes. A trusted agent ${ }^{4}$ was chosen who would keep the money until the delayed delivery date to ensure subjects believed the money would be delivered. The agents were instructed to deliver the money to the respondent, which tried to equalize the pure transaction costs of receiving money immediately (i.e. at the end of the experiment) or in the future. In the latter case, the participant placed the money into an envelope, sealed it, and wrote his (her) name and the date of delivery on the envelope. All envelopes were given to the trusted agency.

After the instruction, each respondent in our experiment was given payoff tables as shown in appendix B to elicit their discount rates for money and present bias. Each payoff matrix gives the respondent the choice to choose between plan A, corresponding to an amount $y$ euro over a period of 3 days to 3 months, and plan B to earn an amount $x$ today. Whilst the amount earned in option A remains constant, the amount earned increases in option B as the respondent moves down the five games in each of the 15 series considered. As in the previous experiment, to determine the amount of money the respondent took home and when, a bingo cage containing 75 numbered balls was used. At the end of the experiment, each respondent was asked to draw one ball to determine which game would be played for real money. The amount earned varied between 0.5 euros and 30 euros. As an example, from appendix B, suppose that the i-th respondent drew ball 21. If he or she had chosen plan A, then he/she would be paid 30 euros in 1 month (the money was placed in an envelope, was closed and signed by the respondent, and delivered to the trusted agent). However, if he/she had chosen plan $\mathrm{B}$, then he/she received 5 euros on the same day of the experiment.

\footnotetext{
${ }^{4}$ In this study, the trusted agent was the recruitment company, as normally citizens participating in our experiment are recruited between 8 to 12 times during the year, by this company, to participate in other experiments.
} 
1 The probability that respondent $i$ will choose an immediate reward $x$ over the delayed reward

$2 y$ in $t$ days by $\mathrm{P}(\mathrm{x}>(\mathrm{y}, \mathrm{t}))$ was described by the logistic function:

3

$$
P(x>(y, t)) \frac{1}{\left.1+\exp \left(-\mu(x-y) \beta(1-(1-\theta) r t)^{1 / 1-\theta}\right)\right)}
$$

4 The time-preference parameters $r, \beta$, and $\theta$ are recovered from the logistic regression 5 function, where $\mu$ is the noise coefficient.

\section{$6 \quad 4 . \quad$ Results}

\subsection{Some preliminary results}

The main household characteristics of the sample used in this paper are shown in Table 3. About $69 \%$ of the respondents in our dataset were married, the remaining being single, divorced, or widowed. More than $90 \%$ of the respondents had more than a basic education: trained professionals or secondary school or university graduates. About $32 \%$ of the respondents earned the average salary in the Metropolitan Area of Barcelona (Spain) with the rest earning more than the average salary. The average weight and height in our sample were $69.88 \mathrm{~kg}$ and 1.66 meters, respectively, leading to an average BMI of $25.36 \mathrm{~kg} / \mathrm{m}^{2}$.

Paste Table 3 here

The BMI distribution among the sample is shown in Figures 1 and 2. The distribution was skewed to the right, indicating that the majority of the respondents had a BMI greater than the $25 \mathrm{~kg} / \mathrm{m}^{2}$. Only one respondent had a BMI greater than $40 \mathrm{~kg} / \mathrm{m}^{2}$. Overweight and obese people represented 37.8 and 10.9 percent of the sample, respectively. These figures are close to those estimated for the Barcelona population in 2012 by the Public Health Department ${ }^{5}$ (35.2\% of the populace were overweight and $13.8 \%$ were obese).

Paste Figure 1 here

Paste Figure 2 here

In relation to risk attitudes, Table 4 shows the average number of choices made by respondents in series 1 and 2 (see Appendix A). The numbers in the first column and row correspond to the switching points in series 1 and 2. The frequency numbers in the table represent the number of subjects who switched at that particular combination of switching points in series 1 and 2. The bolded figures correspond to the number of respondents whose choices would correspond to those predicted by the expected utility. As can be observed, for

\footnotetext{
${ }^{5}$ https://www.diba.cat/es/web/entorn-urba-i-salut/sobrepes-i-obesitat
} 
this particular experiment, the results indicate that the majority of the respondents made their choices outside the expected utility (EU) theory.

Paste Table 4 here

The calculated prospect theory (PT) parameters are shown in Table 5. The average riskaversion parameter was 0.588 , indicating that, on average, respondents are risk averse. The average loss-aversion parameter is 3.67, which also indicates that, globally, respondents are loss averse. The average of the nonlinear probability-weighting parameter is 0.69 (less than 1), meaning that the majority of the respondents have a tendency to overweigh low probabilities. According to Tanaka et al. (2010), if $\gamma=1$ and $\lambda=1$, then the utility function reduces to the EU function. We strongly reject this hypothesis in our experiment, indicating that PT is the adequate framework to analyse risk preferences within our sample. In addition to the calculated sample averages, Figure 3 and Figure 4 show the normal distribution of the risk-aversion and loss-aversion coefficients among participants, respectively. The distribution of the risk-aversion coefficient shows an affinity toward lower risk since the majority of the respondents are found on the left side of the normal distribution. In relation to loss aversion, Figure 4 does not support the absence of loss aversion since the coefficient is above 0 . Most respondents have a loss-aversion coefficient between 0.06 and 11.79; larger loss-aversion coefficients indicate a higher aversion to losses.

Paste Figure 3 here

Paste Figure 4 here

Paste Table 5 here

\subsection{Risk Preferences and Body Mass Index}

To analyse the relationship between risk preferences and BMI, we estimated, by ordinary least squares, three regressions of the curvature of the utility function $(\sigma)$, the loss aversion parameter $(\lambda)$, and probability-weighting parameter $(\gamma)$ against BMI, while controlling for socioeconomic characteristics. Robust standard errors are reported for all three equations in Table 6. As can be observed, we have found a significant positive relationship between risk aversion and BMI indicating that less risk averse persons have a higher propensity to develop higher BMI. This result is consistent with previous studies by Anderson and Mellor (2008) and de Oliveira et al. (2016). This results also confirms the rational addiction theory, which postulate that less risk averse individuals are willing to take the risk of eating unhealthy foods 
1 despite the negative health consequences. No significant relationship was found between loss aversion and probability weighting and BMI. This means that even though obese people are less risk averse, the propensity to become obese is independent of subjects’ aversion to loss.

Some control covariates had significant relationships with the curvature of the utility function $(\sigma)$, the loss-aversion parameter $(\lambda)$, and the probability-weighting parameter $(\gamma)$. The strongest effects suggest older subjects were more risk averse, while lower income subjects were less risk-averse. These results confirm hypothetical studies that found older adults to be more risk averse (Botwinick and Thompson, 1966; Kogan and Wallach, 1961). The relationship between income and risk tend to contradict previous studies that found that risk aversion reduces some as income increases (Barsky et al., 1997; Donkers et al., 2001). Studies like Levin et al. (1988) found that women are more risk averse than men. However, we did not find any significant results.

Paste Table 6 here

\subsection{Time Preferences and Body Mass Index}

A significant share of previous literature that tried to elicit individual time preferences was based on the estimation of an exponential discounting model. However, this model has often been rejected by experimental and field data (Frederick et al., 2002). The results in Table 7 show that we have estimated four time-preference models, with equations 1-3 being nested in equation 4 based on restrictions imposed on beta $(\beta)$ and/or theta $(\theta)$. The statistical performance, in terms of the $\mathrm{R}^{2}$, improves from equation 1 to equation 3 . This suggests that the quasi-hyperbolic and the general model with unrestricted beta and theta are superior to the exponential and hyperbolic models. The advantage of the quasi-hyperbolic model over both the exponential and hyperbolic model is that, with beta being unrestricted, the quasihyperbolic model allows the estimation of both present bias and discount rate. Similarly, the general model goes further to estimate hyperbolicity $(\theta)$ of the preference model (see Tanaka et al., 2010). From the general model, the parameters for discount rate, present bias, and hyperbolicity are $0.006,0.82$, and 3.513 , respectively. This implies that our respondents should trade 78.99 euros today for 100 euros in a week and 71.27 today for 100 euros in one month. However, estimating the general model with unrestricted $\theta$ does not improve $\mathrm{R}^{2}$ compared with the estimation of the quasi-hyperbolic model, so we only focused our attention on the quasi-hyperbolic discounting. 
1 To identify the relationship between the time preference and subjects' demographic

2 covariates, we introduced BMI and control covariates into the quasi-hyperbolic time-

3 preference model. The quasi-hyperbolic time-preference parameters were derived using the

4 logistic model described below:

$5 \quad(x>(y, t)) \frac{1}{1+\exp (-\mu(x-y \beta \exp [r t])))}$

6 where $\beta=\beta_{0}+\sum \beta_{i} X_{i}, \quad r=r_{0}+\sum r_{i} X_{i}, \quad X_{i}$ are demographic variables described above.

$7 \quad \beta_{i}$ and $r_{i}$ are the estimated coefficients associated with the $X_{i}$.

8 Estimated parameters from both equations are shown in Table 8. As can be observed, BMI is 9 positively correlated with impatience (higher discount rates). The implication is that people who are impatient have a tendency to develop higher BMI. This result is consistent with that from Borghans and Golsteyn (2006); Scharff (2009); Smith et al. (2005); Weller et al. (2008); and Zhang and Rashad (2008) who showed that impatience positively correlates with a higher BMI.

Among the socioeconomic covariates, people with only a primary education are more impatient as compared to people with a secondary and university education. Fuchs (1982), Huffman et al. (2017) and Tanaka et al. (2010) also found lower discount rates among highly educated people. This is plausible as people who drop out of school usually prefer to work and earn an income as soon as possible seeing the benefit of higher education as delaying the gratification from today's income. Finally, we have found that females are more impatient than males in the study area, while Dittrich and Leipold (2014) showed the contrary.

Present bias is significant at the 1\% level, suggesting the existence of present bias among respondents. Tanaka et al. (2010) also found the existence of present bias among farmers in Vietnam. While Courtemanche et al. (2015) predicted that present bias increases with BMI, this study shows that present bias increases with BMI only among women.

Paste Table 8 here

\section{Conclusions}

Obesity in Spain is on the rise despite the numerous sociopolitical and socioeconomic policies that have been implemented during the past decades. The framework of rational addiction models the behaviour of individuals from the context of risk and time preferences. 
1 Therefore, many hypothetical studies have suggested a strong correlation between risk, time

2 preferences, and obesity rates. However, no such empirical study has been carried out in

3 Spain to ascertain whether such a relationship exists.

4 The aim of this study was to investigate and ascertain the relationship between risk attitudes, 5 time preferences, and BMI in Spain. We used the experimental approach of Tanaka et al. based on the prospect theory framework to estimate three risk preference parameters: risk aversion, loss aversion, and probability weighting. Similarly, based on the experimental approach of Tanaka et al. and the empirical framework of Benhabib et al. 2007, we estimated four time-preference models (exponential, hyperbolic, quasi-hyperbolic, and the general model); in the quasi-hyperbolic model, we tested for the relationships between present bias and time discounting and obesity.

The experimental data shows the existence of risk aversion, aversion toward losses, and impatience among our respondents. BMI was significant and positively associated with risk aversion. In addition, impatience was found to be highly associated with people with a high BMI. Our results also confirm that risk and time preferences are independent of the methodological framework. No significant relationship exists between probability weighting, loss aversion, and present bias and BMI among our subjects.

Considering the importance of risk and time preferences on the development of obesity, economic policies should begin to factor such individual heterogeneity into economic policy instruments. For instance, policy recommendations that suggest taxes or fiscal policies can influence consumer behaviour leading to a reduction in obesity should consider psychological differences in demand modelling. In addition, the government should develop policies targeted at specific segments of the society instead of a one-for-all policy goal that yields little or no results.

\section{References}

Allison, D.B., Fontaine, K.R., Manson, J.E., Stevens, J., VanItallie, T.B., 1999. Annual deaths attributable to obesity in the United States. Jama 282, 1530-1538.

Anderson, C., Galinsky, A.D., 2006. Power, optimism, and risk-taking. Eur. J. Soc. Psychol. 36, 511-536.

Anderson, L.R., Mellor, J.M., 2008. Predicting health behaviors with an experimental measure of risk preference. J. Health Econ. 27, 1260-1274.

Appelhans, B.M., Waring, M.E., Schneider, K.L., Pagoto, S.L., DeBiasse, M.A., Whited, 
M.C., Lynch, E.B., 2012. Delay discounting and intake of ready-to-eat and away-fromhome foods in overweight and obese women. Appetite 59, 576-584.

Barsky, R.B., Juster, F.T., Kimball, M.S., Shapiro, M.D., 1997. Preference parameters and behavioral heterogeneity: An experimental approach in the health and retirement study. Q. J. Econ. 112, 537-579.

Becker, G.S., Murphy, K.M., 1988. A theory of rational addiction. J. Polit. Econ. 96, 675700.

Benhabib, J., Bisin, A., Schotter, A., 2010. Present-bias, quasi-hyperbolic discounting, and fixed costs. Games Econ. Behav. 69, 205-223.

Benhabib, J., Bisin, A., Schotter, A., 2004. Hyperbolic discounting: An experimental analysis, in: Society for Economic Dynamics Meeting Papers.

Borghans, L., Golsteyn, B.H.H., 2006. Time discounting and the body mass index: Evidence from the Netherlands. Econ. Hum. Biol. 4, 39-61.

Bornovalova, M.A., Daughters, S.B., Hernandez, G.D., Richards, J.B., Lejuez, C.W., 2005. Differences in impulsivity and risk-taking propensity between primary users of crack cocaine and primary users of heroin in a residential substance-use program. Exp. Clin. Psychopharmacol. 13, 311.

Botwinick, J., Thompson, L.W., 1966. Components of reaction time in relation to age and sex. J. Genet. Psychol. 108, 175-183.

Cawley, J., 1999. Obesity and addiction. Chicago, Univ. Chicago.

Charness, G., Gneezy, U., Imas, A., 2013. Experimental methods: Eliciting risk preferences. J. Econ. Behav. Organ. 87, 43-51.

Colditz, G.A., 1992. Economic costs of obesity. Am. J. Clin. Nutr. 55, 503S--507S.

Costa-Font, J., Gil, J., 2006. Revisiting the Fat and Jolly hypothesis: socio-environmental determinants of obesity and depression in Spain. Socio-Economic Rev. 4, 513.

Courtemanche, C., Heutel, G., McAlvanah, P., 2015. Impatience, incentives and obesity. Econ. J. 125, 1-31.

Cutler, D.M., Glaeser, E., 2005. What explains differences in smoking, drinking, and other health-related behaviors? Am. Econ. Rev. 95, 238-242.

Dave, C., Eckel, C.C., Johnson, C.A., Rojas, C., 2010. Eliciting risk preferences: When is simple better? J. Risk Uncertain. 41, 219-243.

Dave, D., Saffer, H., 2008. Alcohol demand and risk preference. J. Econ. Psychol. 29, 810831.

Davis, C., Patte, K., Curtis, C., Reid, C., 2010. Immediate pleasures and future consequences. A neuropsychological study of binge eating and obesity. Appetite 54, 208-213.

de Oliveira, A.C.M., Leonard, T.C.M., Shuval, K., Skinner, C.S., Eckel, C., Murdoch, J.C., 2016. Economic preferences and obesity among a low-income African American community. J. Econ. Behav. Organ. 131, 196-208. 
Dittrich, M., Leipold, K., 2014. Gender differences in time preferences. Econ. Lett. 122, 413415.

Donkers, B., Melenberg, B., Van Soest, A., 2001. Estimating risk attitudes using lotteries: A large sample approach. J. Risk Uncertain. 22, 165-195.

Eckel, C.C., Grossman, P.J., 2008. Forecasting risk attitudes: An experimental study using actual and forecast gamble choices. J. Econ. Behav. Organ. 68, 1-17.

Fecteau, S., Pascual-Leone, A., Zald, D.H., Liguori, P., Théoret, H., Boggio, P.S., Fregni, F., 2007. Activation of prefrontal cortex by transcranial direct current stimulation reduces appetite for risk during ambiguous decision making. J. Neurosci. 27, 6212-6218.

Fishburn, P.C., Rubinstein, A., 1982. Time preference. Int. Econ. Rev. (Philadelphia). 677694.

Frederick, S., Loewenstein, G., O’donoghue, T., 2002. Time discounting and time preference: A critical review. J. Econ. Lit. 40, 351-401.

Fuchs, V.R., 1982. Introduction to" Economic Aspects of Health", in: Economic Aspects of Health. University of Chicago Press, pp. 1-12.

Gutiérrez-Fisac, J.L., Guallar-Castillón, P., León-Muñoz, L.M., Graciani, A., Banegas, J.R., Rodriguez-Artalejo, F., 2012. Prevalence of general and abdominal obesity in the adult population of Spain, 2008--2010: the ENRICA study. Obes. Rev. 13, 388-392.

Hanoch, Y., Johnson, J.G., Wilke, A., 2006. Domain specificity in experimental measures and participant recruitment: An application to risk-taking behavior. Psychol. Sci. 17, 300-304.

Harrison, G.W., Humphrey, S.J., Verschoor, A., 2010. Choice under uncertainty: evidence from Ethiopia, India and Uganda. Econ. J. 120, 80-104.

Holt, C.A., Laury, S.K., 2002. Risk aversion and incentive effects. Am. Econ. Rev. 92, 16441655.

Huffman, D., Maurer, R., Mitchell, O.S., 2017. Time discounting and economic decisionmaking in the older population. J. Econ. Ageing.

Hunt, M.K., Hopko, D.R., Bare, R., Lejuez, C.W., Robinson, E. V, 2005. Construct validity of the balloon analog risk task (BART) associations with psychopathy and impulsivity. Assessment 12, 416-428.

Ida, T., Goto, R., 2009. Simultaneous measurement of time and risk preferences: stated preference discrete choice modeling analysis depending on smoking behavior. Int. Econ. Rev. (Philadelphia). 50, 1169-1182.

Jaroni, J.L., Wright, S.M., Lerman, C., Epstein, L.H., 2004. Relationship between education and delay discounting in smokers. Addict. Behav. 29, 1171-1175.

Kahneman, D., Knetsch, J.L., Thaler, R.H., 1991. Anomalies: The endowment effect, loss aversion, and status quo bias. J. Econ. Perspect. 5, 193-206.

Kahneman, D., Tversky, A., 1979. Prospect Theory: An Analysis of Decision under Risk. 
Econometrica 47, 263-292. https://doi.org/10.2307/1914185

Kirby, K.N., Maraković, N.N., 1995. Modeling myopic decisions: Evidence for hyperbolic delay-discounting within subjects and amounts. Organ. Behav. Hum. Decis. Process. 64, 22-30.

Kogan, N., Wallach, M.A., 1961. Age changes in values and attitudes. J. Gerontol. 16, 272280.

Komlos, J., Smith, P.K., Bogin, B., 2004. Obesity and the rate of time preference: is there a connection? J. Biosoc. Sci. 36, 209-219.

Laibson, D., 1997. Golden eggs and hyperbolic discounting. Q. J. Econ. 112, 443-478.

Lee, N.C., De Groot, R.H.M., Boschloo, A., Dekker, S., Krabbendam, L., Jolles, J., 2013. Age and educational track influence adolescent discounting of delayed rewards. Front. Psychol. 4, 993.

Leitch, M.A., Morgan, M.J., Yeomans, M.R., 2013. Different subtypes of impulsivity differentiate uncontrolled eating and dietary restraint. Appetite 69, 54-63.

Lejuez, C.W., Read, J.P., Kahler, C.W., Richards, J.B., Ramsey, S.E., Stuart, G.L., Strong, D.R., Brown, R.A., 2002. Evaluation of a behavioral measure of risk taking: the Balloon Analogue Risk Task (BART). J. Exp. Psychol. Appl. 8, 75.

Levin, I.P., Snyder, M.A., Chapman, D.P., 1988. The interaction of experiential and situational factors and gender in a simulated risky decision-making task. J. Psychol. 122, $173-181$.

Liu, E.M., Huang, J., 2013. Risk preferences and pesticide use by cotton farmers in China. J. Dev. Econ. 103, 202-215.

Mazur, J.E., 1987. An adjusting procedure for studying delayed reinforcement. Commons, ML.; Maz. JE.; Nevin, JA 55-73.

McGinnis, J.M., Foege, W.H., 1993. Actual causes of death in the United States. Jama 270, 2207-2212.

McLaren, L., 2007. Socioeconomic status and obesity. Epidemiol. Rev. 29, 29-48.

Myerson, J., Green, L., 1995. Discounting of delayed rewards: Models of individual choice. J. Exp. Anal. Behav. 64, 263-276.

Nguyen, Q., Leung, P., 2009. Do fishermen have different attitudes toward risk? An application of prospect theory to the study of Vietnamese fishermen. J. Agric. Resour. Econ. 518-538.

OECD, 2017. Obesity Update 2017. Diabetologe 13, 331-341. https://doi.org/10.1007/s11428-017-0241-7

Reimers, S., Maylor, E.A., Stewart, N., Chater, N., 2009. Associations between a one-shot delay discounting measure and age, income, education and real-world impulsive behavior. Pers. Individ. Dif. 47, 973-978.

Reynaud, A., Couture, S., 2012. Stability of risk preference measures: results from a field 

experiment on French farmers. Theory Decis. 73, 203-221.

Reynolds, B., Richards, J.B., Horn, K., Karraker, K., 2004. Delay discounting and probability discounting as related to cigarette smoking status in adults. Behav. Processes 65, 35-42.

Rollins, B.Y., Dearing, K.K., Epstein, L.H., 2010. Delay discounting moderates the effect of food reinforcement on energy intake among non-obese women. Appetite 55, 420-425.

Scharff, R.L., 2009. Obesity and hyperbolic discounting: Evidence and implications. J. Consum. Policy 32, 3-21.

Smith, P.K., Bogin, B., Bishai, D., 2005. Are time preference and body mass index associated?: Evidence from the National Longitudinal Survey of Youth. Econ. Hum. Biol. 3, 259-270.

Steinberg, L., Graham, S., O’Brien, L., Woolard, J., Cauffman, E., Banich, M., 2009. Age differences in future orientation and delay discounting. Child Dev. 80, 28-44.

Sturm, R., 2002. The effects of obesity, smoking, and drinking on medical problems and costs. Health Aff. 21, 245-253.

Tanaka, T., Camerer, C.F., Nguyen, Q., 2010. Risk and time preferences: linking experimental and household survey data from Vietnam. Am. Econ. Rev. 100, 557-571.

Thaler, R., 1980. Toward a positive theory of consumer choice. J. Econ. Behav. Organ. 1, 39-60.

Thaler, R.H., Shefrin, H.M., 1981. An economic theory of self-control. J. Polit. Econ. 89, 392-406.

Tversky, A., Kahneman, D., 1992. Advances in prospect theory: Cumulative representation of uncertainty. J. Risk Uncertain. 5, 297-323.

Weber, E.U., Blais, A.-R., Betz, N.E., 2002. A domain-specific risk-attitude scale: Measuring risk perceptions and risk behaviors. J. Behav. Decis. Mak. 15, 263-290.

Weller, R.E., Cook III, E.W., Avsar, K.B., Cox, J.E., 2008. Obese women show greater delay discounting than healthy-weight women. Appetite 51, 563-569.

WHO, 2016. Fiscal policies for diet and prevention of noncommunicable diseases: technical meeting report, 5-6 May 2015, Geneva, Switzerland. World Health Organization.

Wolf, A.M., Colditz, G.A., 1998. Current estimates of the economic cost of obesity in the United States. Obesity 6, 97-106.

Zhang, L., Rashad, I., 2008. Obesity and time preference: the health consequences of discounting the future. J. Biosoc. Sci. 40, 97-113. 
1 Table 1 Switching point (question) in Series 1 and 2, and approximations of $\sigma$ (parameter for the curvature of power value function/risk 2 parameter)

\begin{tabular}{|c|c|c|c|c|c|c|c|c|c|c|c|c|c|c|c|}
\hline \multicolumn{7}{|l|}{$\sigma$} & \multicolumn{9}{|c|}{ Switching point for series 1} \\
\hline Series & 1 & 2 & 3 & 4 & 5 & 6 & 7 & 8 & 9 & 10 & 11 & 12 & 13 & 14 & Never \\
\hline \multicolumn{16}{|l|}{2} \\
\hline 1 & 1.50 & 1.40 & 1.35 & 1.25 & 1.15 & 1.10 & 1.00 & 0.95 & 0.90 & 0.85 & 0.80 & 0.75 & 0.65 & 0.55 & 0.50 \\
\hline 2 & 1.40 & 1.30 & 1.25 & 1.15 & 1.10 & 1.00 & 0.95 & 0.90 & 0.85 & 0.80 & 0.75 & 0.70 & 0.60 & 0.55 & 0.50 \\
\hline 3 & 1.30 & 1.20 & 1.15 & 1.10 & 1.00 & 0.95 & 0.90 & 0.85 & 0.80 & 0.75 & 0.70 & 0.65 & 0.55 & 0.50 & 0.45 \\
\hline 4 & 1.20 & 1.15 & 1.05 & 1.00 & 0.95 & 0.90 & 0.85 & 0.80 & 0.75 & 0.70 & 0.65 & 0.55 & 0.50 & 0.45 & 0.40 \\
\hline 5 & 1.15 & 1.05 & 1.00 & 0.95 & 0.90 & 0.85 & 0.80 & 0.75 & 0.70 & 0.65 & 0.55 & 0.50 & 0.45 & 0.40 & 0.35 \\
\hline 6 & 1.05 & 1.00 & 0.95 & 0.90 & 0.85 & 0.80 & 0.75 & 0.70 & 0.65 & 0.60 & 0.55 & 0.50 & 0.45 & 0.40 & 0.35 \\
\hline 7 & 1.00 & 0.95 & 0.90 & 0.85 & 0.80 & 0.75 & 0.70 & 0.65 & 0.60 & 0.55 & 0.50 & 0.45 & 0.40 & 0.35 & 0.30 \\
\hline 8 & 0.95 & 0.90 & 0.85 & 0.80 & 0.75 & 0.70 & 0.65 & 0.60 & 0.55 & 0.50 & 0.45 & 0.40 & 0.35 & 0.30 & 0.25 \\
\hline 9 & 0.90 & 0.85 & 0.80 & 0.75 & 0.70 & 0.65 & 0.60 & 0.55 & 0.50 & 0.45 & 0.40 & 0.35 & 0.30 & 0.25 & 0.20 \\
\hline 10 & 0.85 & 0.80 & 0.75 & 0.70 & 0.65 & 0.60 & 0.55 & 0.50 & 0.45 & 0.40 & 0.35 & 0.30 & 0.25 & 0.20 & 0.20 \\
\hline 11 & 0.80 & 0.70 & 0.65 & 0.60 & 0.65 & 0.55 & 0.50 & 0.45 & 0.40 & 0.35 & 0.30 & 0.25 & 0.20 & 0.15 & 0.15 \\
\hline 12 & 0.75 & 0.65 & 0.60 & 0.55 & 0.50 & 0.50 & 0.45 & 0.40 & 0.35 & 0.30 & 0.25 & 0.20 & 0.20 & 0.15 & 0.10 \\
\hline 13 & 0.65 & 0.60 & 0.55 & 0.50 & 0.45 & 0.45 & 0.40 & 0.35 & 0.30 & 0.25 & 0.20 & 0.15 & 0.15 & 0.10 & 0.10 \\
\hline 14 & 0.60 & 0.55 & 0.50 & 0.45 & 0.40 & 0.35 & 0.35 & 0.30 & 0.25 & 0.20 & 0.15 & 0.10 & 0.10 & 0.10 & 0.05 \\
\hline Never & 0.50 & 0.45 & 0.40 & 0.40 & 0.35 & 0.30 & 0.30 & 0.25 & 0.20 & 0.15 & 0.10 & 0.10 & 0.05 & 0.05 & 0.05 \\
\hline
\end{tabular}


1 Table 2 Switching point (question) in Series 1 and 2, and $\alpha$ (probability sensitivity parameter in Prelec's weighting function)

\begin{tabular}{|c|c|c|c|c|c|c|c|c|c|c|c|c|c|c|c|}
\hline$\alpha$ & \multicolumn{15}{|c|}{ Switching question in series 1} \\
\hline $\begin{array}{l}\text { Series } \\
2\end{array}$ & 1 & 2 & 3 & 4 & 5 & 6 & 7 & 8 & 9 & 10 & 11 & 12 & 13 & 14 & Never \\
\hline 1 & 0.60 & 0.75 & 0.75 & 0.85 & 0.90 & 0.95 & 1.00 & 1.05 & 1.10 & 1.15 & 1.20 & 1.25 & 1.30 & 1.40 & 1.45 \\
\hline 2 & 0.60 & 0.70 & 0.75 & 0.80 & 0.85 & 0.90 & 0.95 & 1.00 & 1.05 & 1.10 & 1.15 & 1.20 & 1.25 & 1.35 & 1.40 \\
\hline 3 & 0.55 & 0.60 & 0.70 & 0.75 & 0.80 & 0.85 & 0.90 & 0.95 & 1.00 & 1.05 & 1.10 & 1.15 & 1.20 & 1.25 & 1.30 \\
\hline 4 & 0.50 & 0.60 & 0.65 & 0.70 & 0.75 & 0.80 & 0.85 & 0.90 & 0.95 & 1.00 & 1.05 & 1.10 & 1.15 & 1.20 & 1.25 \\
\hline 5 & 0.45 & 0.55 & 0.60 & 0.65 & 0.70 & 0.75 & 0.80 & 0.85 & 0.90 & 0.95 & 1.00 & 1.05 & 1.10 & 1.15 & 1.20 \\
\hline 6 & 0.45 & 0.50 & 0.55 & 0.60 & 0.65 & 0.70 & 0.75 & 0.80 & 0.85 & 0.90 & 0.95 & 1.00 & 1.05 & 1.10 & 1.15 \\
\hline 7 & 0.40 & 0.45 & 0.50 & 0.55 & 0.60 & 0.65 & 0.70 & 0.75 & 0.80 & 0.85 & 0.90 & 0.95 & 1.00 & 1.05 & 1.10 \\
\hline 8 & 0.35 & 0.40 & 0.45 & 0.50 & 0.55 & 0.60 & 0.65 & 0.70 & 0.75 & 0.80 & 0.85 & 0.90 & 0.95 & 1.00 & 1.05 \\
\hline 9 & 0.30 & 0.35 & 0.40 & 0.45 & 0.50 & 0.55 & 0.60 & 0.65 & 0.70 & 0.75 & 0.80 & 0.85 & 0.90 & 0.95 & 1.00 \\
\hline 10 & 0.25 & 0.30 & 0.35 & 0.40 & 0.45 & 0.50 & 0.55 & 0.60 & 0.65 & 0.70 & 0.75 & 0.80 & 0.85 & 0.90 & 0.95 \\
\hline 11 & 0.20 & 0.25 & 0.30 & 0.35 & 0.40 & 0.45 & 0.50 & 0.55 & 0.60 & 0.65 & 0.70 & 0.75 & 0.80 & 0.85 & 0.90 \\
\hline 12 & 0.15 & 0.20 & 0.25 & 0.30 & 0.35 & 0.40 & 0.45 & 0.50 & 0.55 & 0.60 & 0.65 & 0.70 & 0.75 & 0.80 & 0.85 \\
\hline 13 & 0.10 & 0.15 & 0.20 & 0.25 & 0.30 & 0.35 & 0.40 & 0.45 & 0.50 & 0.55 & 0.60 & 0.65 & 0.70 & 0.75 & 0.80 \\
\hline 14 & 0.05 & 0.10 & 0.15 & 0.20 & 0.25 & 0.30 & 0.35 & 0.40 & 0.45 & 0.50 & 0.55 & 0.60 & 0.65 & 0.70 & 0.75 \\
\hline Never & 0.05 & 0.05 & 0.10 & 0.15 & 0.20 & 0.25 & 0.30 & 0.35 & 0.40 & 0.45 & 0.45 & 0.55 & 0.55 & 0.65 & 0.60 \\
\hline
\end{tabular}


1 Table 3 Household characteristic (\%)

\begin{tabular}{|c|c|c|c|c|}
\hline Variables & Mean & Std. Error & [95\% Conf. & Interval] \\
\hline Probability Weighting & 0.64 & 0.03 & 0.59 & 0.69 \\
\hline Risk Aversion Coefficient & 0.58 & 0.03 & 0.52 & 0.63 \\
\hline Loss Aversion Coefficient & 3.67 & 0.30 & 3.09 & 4.26 \\
\hline Married & 0.69 & 0.04 & 0.62 & 0.76 \\
\hline Age & 46.38 & 1.11 & 44.20 & 48.57 \\
\hline Basic Education & 0.08 & 0.02 & 0.04 & 0.12 \\
\hline Income Less 1500 & 0.32 & 0.04 & 0.25 & 0.39 \\
\hline $\begin{array}{l}\text { Income Between } 1500 \text { And } \\
2500\end{array}$ & 0.42 & 0.04 & 0.34 & 0.49 \\
\hline $\begin{array}{l}\text { Income Between } 2500 \text { And } \\
4000\end{array}$ & 0.19 & 0.03 & 0.13 & 0.25 \\
\hline BMI & 25.36 & 0.32 & 24.53 & 25.80 \\
\hline Body Weight & 69.88 & 1.12 & 67.67 & 72.09 \\
\hline Body Height & 1.66 & 0.01 & 1.65 & 1.68 \\
\hline
\end{tabular}

4

5

6 


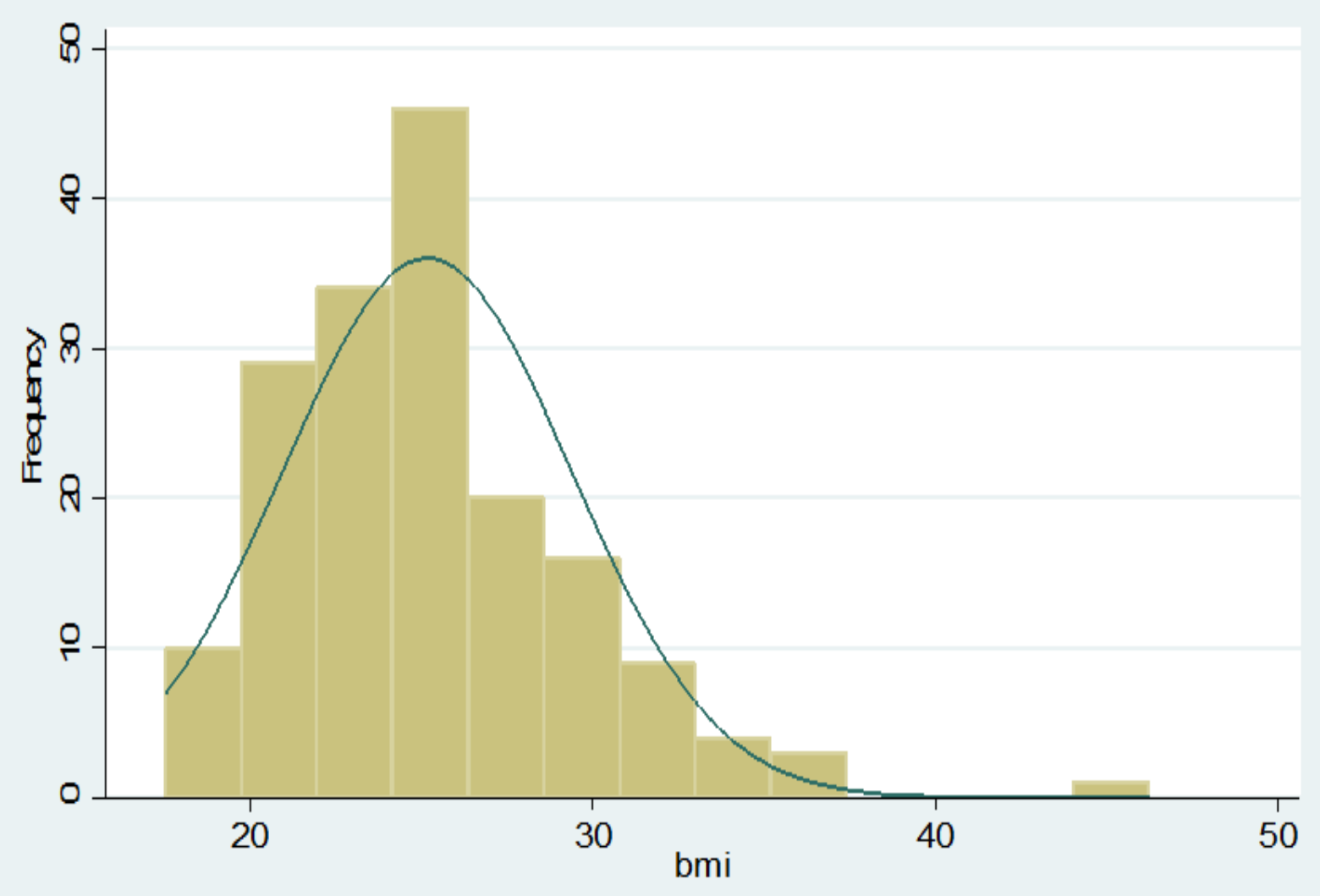

1 Figure 1 Normal and frequency distribution by BMI

2

3

4

5

6

7

8

9

10

11

12 
$60,0 \%$

$50,0 \%$

$40,0 \%$

$30,0 \%$

$20,0 \%$

1

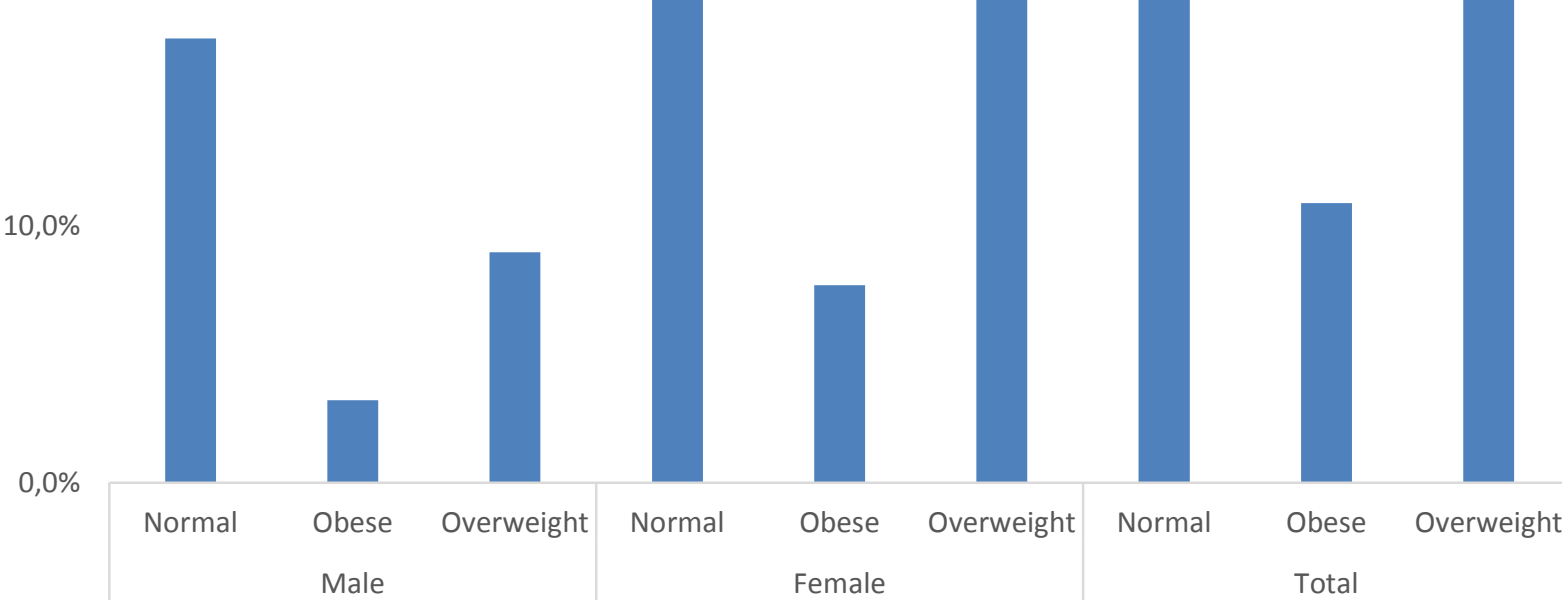

2 Figure 2 Distribution of respondents by BMI

3

4

5

6

7 


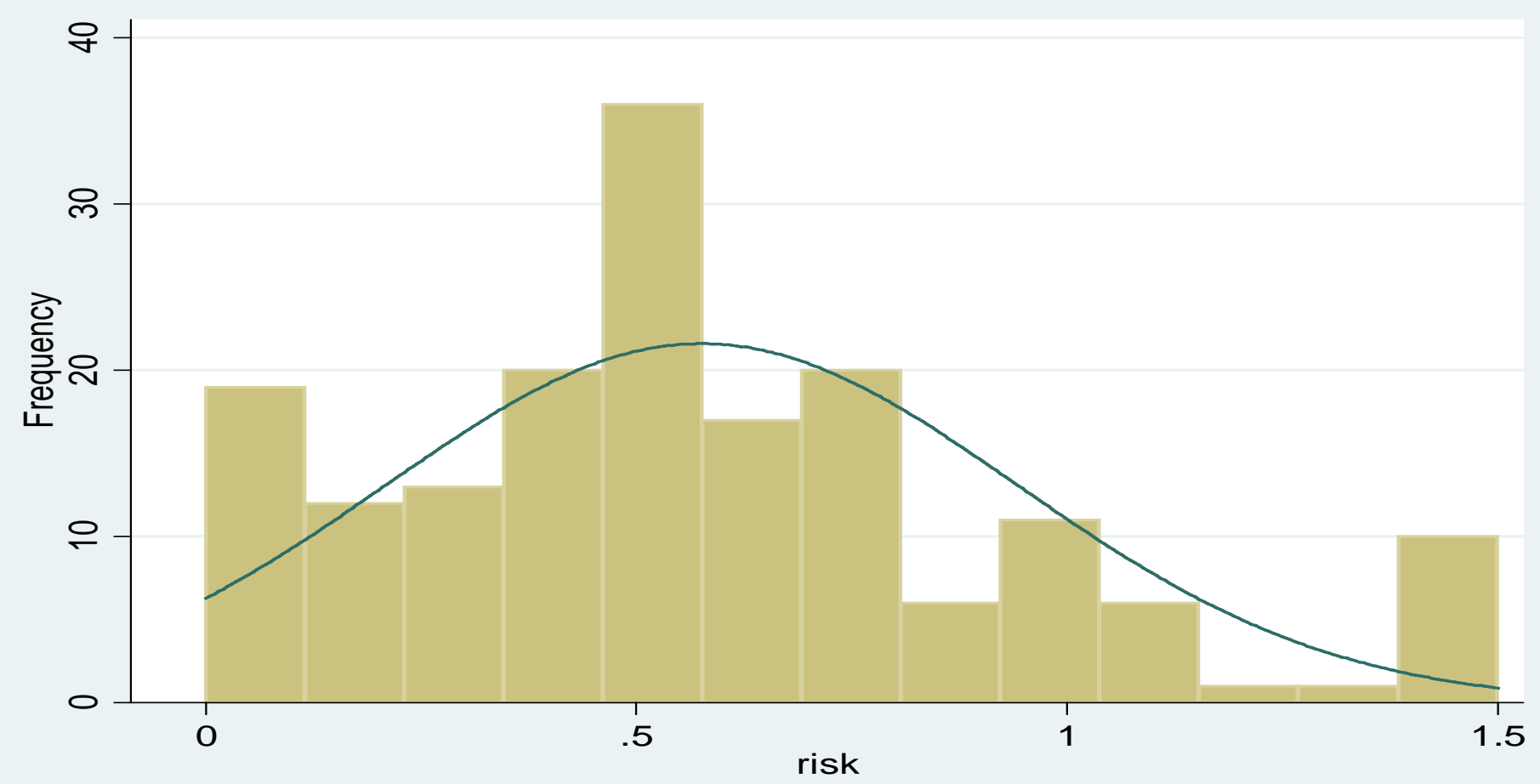

3 Figure 3 Normal and frequency distribution by risk aversion coefficient

4

5

6

7

8

9

10

11

12

13

14

15 


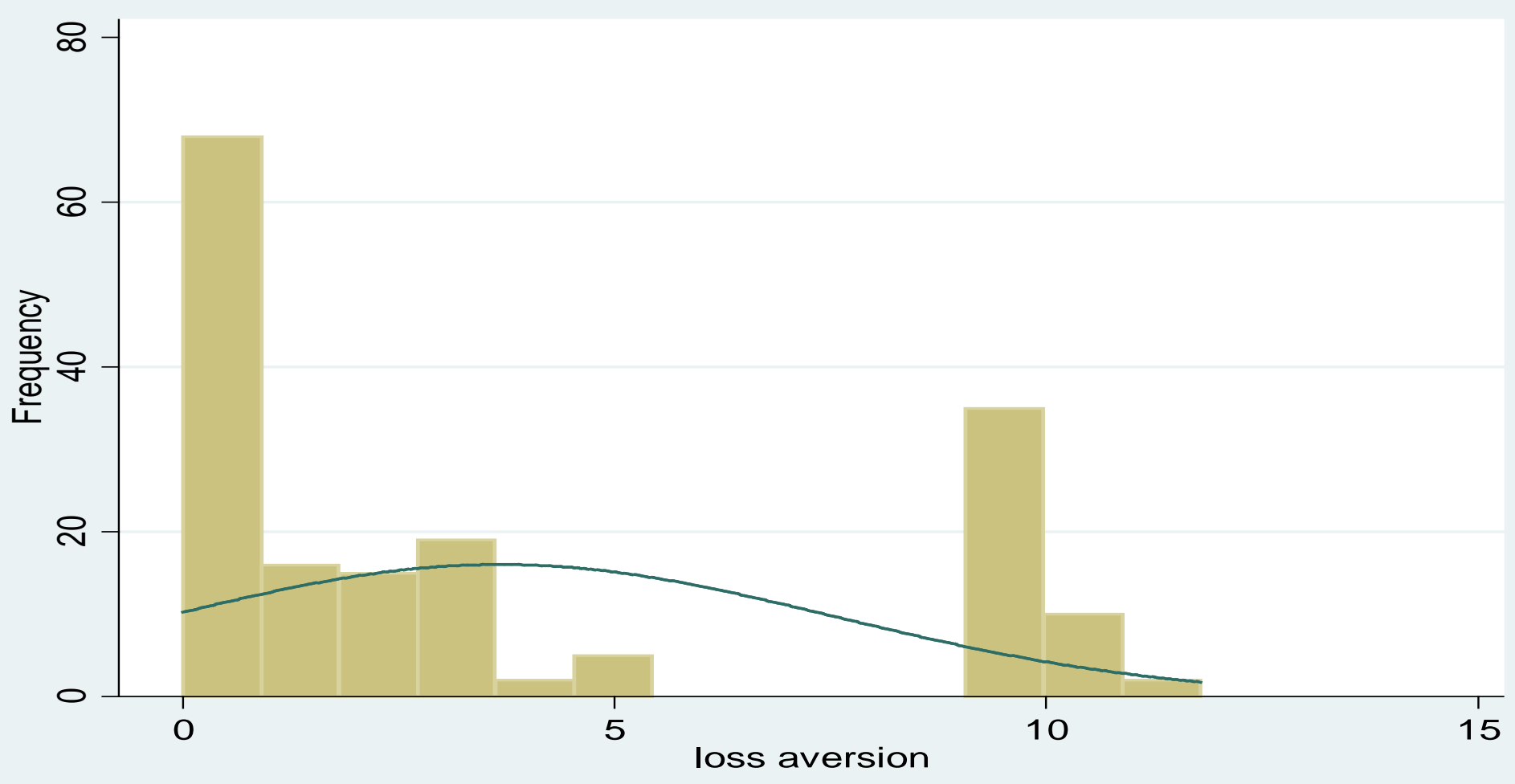

2 Figure 4 Normal and frequency distribution of loss aversion

3

4

5

6

7

8

9

10

11

12

13

14

15

16 
1 Table 4 Distribution of Switching Points in Series 1 and Series 2

\section{Series 1}

\begin{tabular}{|c|c|c|c|c|c|c|c|c|c|c|c|c|c|}
\hline & $\begin{array}{c}\text { Switching } \\
\text { Points }\end{array}$ & Never & 1 & 4 & 5 & 6 & 7 & 8 & 9 & 10 & 11 & 12 & 13 \\
\hline & Never & 6 & 10 & & 2 & 2 & 3 & 4 & 3 & 3 & 3 & 1 & 1 \\
\hline & 1 & 6 & 10 & & 1 & 3 & 2 & 3 & 2 & 2 & 3 & 2 & 1 \\
\hline & 3 & & 1 & 1 & & & & & & & & 1 & \\
\hline & 4 & 1 & 1 & 1 & 1 & & & & 1 & 2 & & & \\
\hline & 5 & & 1 & & & 1 & & & & & & & \\
\hline & 6 & & & & & 2 & & 1 & & & & & \\
\hline & 7 & & & & 1 & 1 & & 2 & & 1 & 1 & & \\
\hline \multirow[t]{7}{*}{ Series 2} & 8 & 1 & 3 & 1 & & 3 & 2 & & 4 & & & & 1 \\
\hline & 9 & & 1 & & 1 & 1 & 4 & 2 & 1 & & 1 & & \\
\hline & 10 & 1 & & & 1 & 2 & & 3 & 4 & & & & \\
\hline & 11 & & & & & & 1 & 1 & 1 & & & & \\
\hline & 12 & 1 & 1 & & 3 & 1 & 1 & 3 & 1 & & 1 & 1 & 1 \\
\hline & 13 & & & & 1 & & & & & & & 2 & \\
\hline & 14 & & & & & & 1 & & & & 1 & 2 & 1 \\
\hline
\end{tabular}

4

5

6

7

8

9

10 
1 Table 5 Risk preference parameters

\begin{tabular}{lllll}
\hline Variables & Mean & Std. Error & [95\% Conf. & Interval] \\
\hline Probability Weighting & 0.64 & 0.03 & 0.59 & 0.69 \\
Risk Aversion Coefficient & 0.58 & 0.03 & 0.52 & 0.63 \\
Loss Aversion Coefficient & 3.67 & 0.30 & 3.09 & 4.26 \\
& & & & \\
\hline
\end{tabular}

2

3

4

5

6

7

8

9

10

11

12

13

14

15

16

17 
1 Table 6 -Correlations with determinants of Risk aversion, Loss aversion and

2 probability sensitivity parameter in Prelec's weighting function

\begin{tabular}{|c|c|c|c|}
\hline Explanatory Variables & Risk aversion & Loss aversion & $\begin{array}{l}\text { Probability } \\
\text { weighting }\end{array}$ \\
\hline Body Mass Index & $0.014(-0.008)^{*}$ & $0.000(0.082)$ & $0.002(0.007)$ \\
\hline Age & $-0.003(-0.002)^{* *}$ & $0.057(0.017)^{* * *}$ & $0.000(0.002)$ \\
\hline Married $=1$ & $0.023(-0.063)$ & $0.995(0.711)$ & $0.023(0.066)$ \\
\hline Gender $($ Female=1) & $-0.103(-0.065)$ & $-0.660(0.717)$ & $-0.087(0.060)$ \\
\hline Education $($ Basic $=1)$ & $0.110(-0.119)$ & $0.574(1.237)$ & $-0.189(0.098)^{*}$ \\
\hline Income (Less $1500=1$ ) & $0.111(-0.056)^{* *}$ & $0.409(0.713)$ & $0.078(0.064)$ \\
\hline Constant & $0.399(-0.207)^{*}$ & $0.562(2.108)$ & $0.622(0.194)^{* * *}$ \\
\hline
\end{tabular}

4

5

6

7

8

9 
1 Table 7 Comparison of Exponential, Hyperbolic, and Quasi-Hyperbolic Discounting

2 Models

\begin{tabular}{|c|c|c|c|c|}
\hline choice & Exponential & Hyperbolic & $\begin{array}{l}\text { Quasi- } \\
\text { hyperbolic }\end{array}$ & Equation (1) \\
\hline Meu & $0.093 * * *$ & $0.093 * * *$ & $0.119 * * *$ & $0.119 * * *$ \\
\hline Rate & $0.009 * * *$ & $0.009 * * *$ & $0.004 * * *$ & $0.006 * * *$ \\
\hline Beta & & & $0.800 * * *$ & $0.816 * * *$ \\
\hline
\end{tabular}

Theta

$3.513^{* * *}$

Adjusted

$\begin{array}{lllll}\text { R-Squared } & 0.5217 & 0.5231 & 0.5278 & 0.5278\end{array}$ 
1 Table 8 - Correlations with Present Bias and Discount Rates (OLS)

Present Bias Discount Rate

$\mu$

$0.130^{* * *}$

Beta/Rate

$1.064 * * *$

$-0.007$

Gender*BMI

0.011*

$-0.033$

Married

0.010

$-0.167$

Gender

$-0.296^{*}$

0.967*

Age

$-0.004$

$-0.0002$

BMI

$-0.006$

$0.038 * *$

Primary

0.024

$0.704 * *$

Age square

$0.00002^{* *}$

0.00006

2

Coefficients of discount rate are multiplied by $100 .{ }^{*}, * *, * * *$ respresent significant at $10 \%$,

$35 \%, 1 \%$, respectively.

4

5

6

7

8

9 
1 Appendix A

\begin{tabular}{|c|c|c|}
\hline Series 1 & Plan A & Plan B \\
\hline 1 & $\begin{array}{l}4 € \text { Yes (1) (2) (3) } \\
1 € \text { Yes (4) (5) (6) (7) (8) (9) (10) }\end{array}$ & $\begin{array}{l}6,8 € \text { Yes (1) } \\
0,5 € \text { Yes (2) (3) (4) (5) (6) (7) (8) (9) (10) }\end{array}$ \\
\hline 2 & $\begin{array}{l}€ \text { Yes (1) (2) (3) } \\
1 € \text { Yes (4) (5) (6) (7) (8) (9) (10) }\end{array}$ & $\begin{array}{l}7,5 € \text { Yes (1) } \\
0,5 € \text { Yes (2) (3) (4) (5) (6) (7) (8) (9) (10) }\end{array}$ \\
\hline 3 & $\begin{array}{l}€ \text { Yes (1) (2) (3) } \\
1 € \text { Yes (4) (5) (6) (7) (8) (9) (10) }\end{array}$ & $\begin{array}{l}8,3 € \text { Yes (1) } \\
0,5 € \text { Yes (2) (3) (4) (5) (6) (7) (8) (9) (10) }\end{array}$ \\
\hline 4 & $\begin{array}{l}€ \text { Yes (1) (2) (3) } \\
1 € \text { Yes (4) (5) (6) (7) (8) (9) (10) }\end{array}$ & $\begin{array}{l}9,3 € \text { Yes (1) } \\
0,5 € \text { Yes (2) (3) (4) (5) (6) (7) (8) (9) (10) }\end{array}$ \\
\hline 5 & $\begin{array}{l}€ \text { Yes (1) (2) (3) } \\
1 € \text { Yes (4) (5) (6) (7) (8) (9) (10) }\end{array}$ & $\begin{array}{l}10,6 € \text { Yes (1) } \\
0,5 € \text { Yes (2) (3) (4) (5) (6) (7) (8) (9) (10) }\end{array}$ \\
\hline 6 & $\begin{array}{l}€ \text { Yes (1) (2) (3) } \\
1 € \text { Yes (4) (5) (6) (7) (8) (9) (10) }\end{array}$ & $\begin{array}{l}12,5 € \text { Yes (1) } \\
0,5 € \text { Yes (2) (3) (4) (5) (6) (7) (8) (9) (10) }\end{array}$ \\
\hline 7 & $\begin{array}{l}4 € \text { Yes (1) (2) (3) } \\
1 € \text { Yes (4) (5) (6) (7) (8) (9) (10) }\end{array}$ & $\begin{array}{l}15,0 € \text { Yes (1) } \\
0,5 € \text { Yes (2) (3) (4) (5) (6) (7) (8) (9) (10) }\end{array}$ \\
\hline 8 & $\begin{array}{l}4 € \text { Yes (1) (2) (3) } \\
1 € \text { Yes (4) (5) (6) (7) (8) (9) (11) }\end{array}$ & $\begin{array}{l}18,5 € \text { Yes (1) } \\
0,5 € \text { Yes (2) (3) (4) (5) (6) (7) (8) (9) (10) }\end{array}$ \\
\hline 9 & $\begin{array}{l}4 € \text { Yes (1) (2) (3) } \\
1 € \text { Yes (4) (5) (6) (7) (8) (9) (10) }\end{array}$ & $\begin{array}{l}22,0 € \text { Yes (1) } \\
0,5 € \text { Yes (2) (3) (4) (5) (6) (7) (8) (9) (10) }\end{array}$ \\
\hline 10 & $\begin{array}{l}€ \text { Yes (1) (2) (3) } \\
1 € \text { Yes (4) (5) (6) (7) (8) (9) (10) }\end{array}$ & $\begin{array}{l}30,0 € \text { Yes (1) } \\
0,5 € \text { Yes (2) (3) (4) (5) (6) (7) (8) (9) (10) }\end{array}$ \\
\hline 11 & $\begin{array}{l}€ \text { Yes (1) (2) (3) } \\
1 € \text { Yes (4) (5) (6) (7) (8) (9) (10) }\end{array}$ & $\begin{array}{l}40,0 € \text { Yes (1) } \\
0,5 € \text { Yes (2) (3) (4) (5) (6) (7) (8) (9) (10) }\end{array}$ \\
\hline 12 & $\begin{array}{l}4 € \text { Yes (1) (2) (3) } \\
1 € \text { Yes (4) (5) (6) (7) (8) (9) (10) }\end{array}$ & $\begin{array}{l}60,0 € \text { Yes (1) } \\
0,5 € \text { Yes (2) (3) (4) (5) (6) (7) (8) (9) (10) }\end{array}$ \\
\hline 13 & $\begin{array}{l}4 € \text { Yes (1) (2) (3) } \\
1 € \text { Yes (4) (5) (6) (7) (8) (9) (10) }\end{array}$ & $\begin{array}{l}100,0 € \text { Yes (1) } \\
0,5 € \text { Yes (2) (3) (4) (5) (6) (7) (8) (9) (10) }\end{array}$ \\
\hline 14 & $\begin{array}{l}4 € \text { Yes (1) (2) (3) } \\
1 € \text { Yes (4) (5) (6) (7) (8) (9) (11) }\end{array}$ & $\begin{array}{l}170,0 € \text { Yes (1) } \\
0,5 € \text { Yes (2) (3) (4) (5) (6) (7) (8) (9) (10) }\end{array}$ \\
\hline & I choose Plan A for Questions 1- & I choose Plan B for Questions___ -14 \\
\hline Series 2 & Plan A & Plan B \\
\hline 15 & $\begin{array}{l}4 € \text { Yes (1) (2) (3) (4) (5) (6) (7) (8) (9) } \\
3 € \text { Yes (10) }\end{array}$ & $\begin{array}{l}5,4 € \text { Yes (1) (2) (3) (4) (5) (6) (7) } \\
0,5 € \text { Yes (8) (9) (10) }\end{array}$ \\
\hline 16 & $\begin{array}{l}4 € \text { Yes (1) (2) (3) (4) (5) (6) (7) (8) (9) } \\
3 € \text { Yes (10) }\end{array}$ & $\begin{array}{l}5,6 € \text { Yes (1) (2) (3) (4) (5) (6) (7) } \\
0,5 € \text { Yes (8) (9) (10) }\end{array}$ \\
\hline 17 & $\begin{array}{l}4 € \text { Yes (1) (2) (3) (4) (5) (6) (7) (8) (9) } \\
3 € \text { Yes (10) }\end{array}$ & $\begin{array}{l}5,8 € \text { Yes (1) (2) (3) (4) (5) (6) (7) } \\
0,5 € \text { Yes (8) (9) (10) }\end{array}$ \\
\hline 18 & $\begin{array}{l}4 € \text { Yes (1) (2) (3) (4) (5) (6) (7) (8) (9) } \\
3 € \text { Yes (10) }\end{array}$ & $\begin{array}{l}6,0 € \text { Yes (1) (2) (3) (4) (5) (6) (7) } \\
0,5 € \text { Yes (8) (9) (10) }\end{array}$ \\
\hline 19 & $\begin{array}{l}4 € \text { Yes (1) (2) (3) (4) (5) (6) (7) (8) (9) } \\
3 € \text { Yes (10) }\end{array}$ & $\begin{array}{l}\text { 6,2€ Yes (1) (2) (3) (4) (5) (6) (7) } \\
0,5 € \text { Yes (8) (9) (10) }\end{array}$ \\
\hline 20 & $\begin{array}{l}4 € \text { Yes (1) (2) (3) (4) (5) (6) (7) (8) (9) } \\
3 € \text { Yes (10) }\end{array}$ & $\begin{array}{l}\text { 6,5€ Yes (1) (2) (3) (4) (5) (6) (7) } \\
0,5 € \text { Yes (8) (9) (10) }\end{array}$ \\
\hline 21 & $\begin{array}{l}4 € \text { Yes (1) (2) (3) (4) (5) (6) (7) (8) (9) } \\
3 € \text { Yes (10) }\end{array}$ & $\begin{array}{l}\text { 6,8€ Yes (1) (2) (3) (4) (5) (6) (7) } \\
0,5 € \text { Yes (8) (9) (10) }\end{array}$ \\
\hline 22 & $\begin{array}{l}4 € \text { Yes (1) (2) (3) (4) (5) (6) (7) (8) (9) } \\
3 € \text { Yes (10) }\end{array}$ & $\begin{array}{l}7,2 € \text { Yes (1) (2) (3) (4) (5) (6) (7) } \\
0,5 € \text { Yes (8) (9) (10) }\end{array}$ \\
\hline
\end{tabular}




\begin{tabular}{|c|c|c|}
\hline 23 & $\begin{array}{l}4 € \text { Yes (1) (2) (3) (4) (5) (6) (7) (8) (9) } \\
3 € \text { Yes (10) }\end{array}$ & $\begin{array}{l}7,7 € \text { Yes (1) (2) (3) (4) (5) (6) (7) } \\
0,5 € \text { Yes (8) (9) (10) }\end{array}$ \\
\hline 24 & $\begin{array}{l}4 € \text { Yes (1) (2) (3) (4) (5) (6) (7) (8) (9) } \\
3 € \text { Yes (10) }\end{array}$ & $\begin{array}{l}8,3 € \text { Yes (1) (2) (3) (4) (5) (6) (7) } \\
0,5 € \text { Yes (8) (9) (10) }\end{array}$ \\
\hline 25 & $\begin{array}{l}4 € \text { Yes (1) (2) (3) (4) (5) (6) (7) (8) (9) } \\
3 € \text { Yes (10) }\end{array}$ & $\begin{array}{l}9,0 € \text { Yes (1) (2) (3) (4) (5) (6) (7) } \\
0,5 € \text { Yes (8) (9) (10) }\end{array}$ \\
\hline 26 & $\begin{array}{l}4 € \text { Yes (1) (2) (3) (4) (5) (6) (7) (8) (9) } \\
3 € \text { Yes (10) }\end{array}$ & $\begin{array}{l}10,0 € \text { Yes (1) (2) (3) (4) (5) (6) (7) } \\
0,5 € \text { Yes (8) (9) (10) }\end{array}$ \\
\hline 27 & $\begin{array}{l}4 € \text { Yes (1) (2) (3) (4) (5) (6) (7) (8) (9) } \\
3 € \text { Yes (10) }\end{array}$ & $\begin{array}{l}11,0 € \text { Yes (1) (2) (3) (4) (5) (6) (7) } \\
0,5 € \text { Yes (8) (9) (10) }\end{array}$ \\
\hline 28 & $\begin{array}{l}4 € \text { Yes (1) (2) (3) (4) (5) (6) (7) (8) (9) } \\
3 € \text { Yes (10) }\end{array}$ & $\begin{array}{l}13,0 € \text { Yes (1) (2) (3) (4) (5) (6) (7) } \\
0,5 € \text { Yes (8) (9) (1) }\end{array}$ \\
\hline & I choose Plan A for Questions 15 - & I choose Plan B for Questions___ 28 \\
\hline Series 3 & $\overline{\text { Plan A }}$ & Plan B \\
\hline 29 & $\begin{array}{ll}\text { Gain } & 2,5 € \text { Yes (1) (2) (3) (4) (5) } \\
\text { Loss } & 0,4 € \text { Yes (6) (7) (8) (9) (10) }\end{array}$ & $\begin{array}{ll}\text { Gain } & 3,0 € \text { Yes (1) (2) (3) (4) (5) } \\
\text { Loss } & 2,1 € \text { Yes (6) (7) (8) (9) (10) }\end{array}$ \\
\hline 30 & $\begin{array}{ll}\text { Gain } & 0,4 € \text { Yes (1) (2) (3) (4) (5) } \\
\text { Loss } & 0,4 € \text { Yes (6) (7) (8) (9) (10) }\end{array}$ & $\begin{array}{ll}\text { Gain } & 3,0 € \text { Yes (1) (2) (3) (4) (5) } \\
\text { Loss } & 2,1 € \text { Yes (6) (7) (8) (9) (11) }\end{array}$ \\
\hline 31 & $\begin{array}{ll}\text { Gain } & 0,1 € \text { Yes (1) (2) (3) (4) (5) } \\
\text { Loss } & 0,4 € \text { Yes (6) (7) (8) (9) (10) }\end{array}$ & $\begin{array}{ll}\text { Gain } & 3,0 € \text { Yes (1) (2) (3) (4) (5) } \\
\text { Loss } & 2,1 € \text { Yes (6) (7) (8) (9) (10) }\end{array}$ \\
\hline 32 & $\begin{array}{ll}\text { Gain } & 0,1 € \text { Yes (1) (2) (3) (4) (5) } \\
\text { Loss } & 0,4 € \text { Yes (6) (7) (8) (9) (10) }\end{array}$ & $\begin{array}{ll}\text { Gain } & 3,0 € \text { Yes (1) (2) (3) (4) (5) } \\
\text { Loss } & 1,6 € \text { Yes (6) (7) (8) (9) (10) }\end{array}$ \\
\hline 33 & $\begin{array}{ll}\text { Gain } & 0,1 € \text { Yes (1) (2) (3) (4) (5) } \\
\text { Loss } & 0,8 € \text { Yes (6) (7) (8) (9) (10) }\end{array}$ & $\begin{array}{ll}\text { Gain } & 3,0 € \text { Yes (1) (2) (3) (4) (5) } \\
\text { Loss } & 1,6 € \text { Yes (6) (7) (8) (9) (10) }\end{array}$ \\
\hline 34 & $\begin{array}{ll}\text { Gain } & 0,1 € \text { Yes (1) (2) (3) (4) (5) } \\
\text { Loss } & 0,8 € \text { Yes (6) (7) (8) (9) (10) }\end{array}$ & $\begin{array}{ll}\text { Gain } & 3,0 € \text { Yes (1) (2) (3) (4) (5) } \\
\text { Loss } & 1,4 € \text { Yes (6) (7) (8) (9) (10) }\end{array}$ \\
\hline 35 & $\begin{array}{ll}\text { Gain } & 0,1 € \text { Yes (1) (2) (3) (4) (5) } \\
\text { Loss } & 0,8 € \text { Yes (6) (7) (8) (9) (10) }\end{array}$ & $\begin{array}{ll}\text { Gain } & 3,0 € \text { Yes (1) (2) (3) (4) (5) } \\
\text { Loss } & 1,1 € \text { Yes (6) (7) (8) (9) (11) }\end{array}$ \\
\hline & I choose Plan A for Questions 29 - & I choose Plan B for Questions___ - 35 \\
\hline
\end{tabular}

1 
Appendix B

\begin{tabular}{|c|c|c|}
\hline & Plan A & Plan B \\
\hline 1 & Receive $12 €$ in a week & Receive $2 €$ today \\
\hline 2 & Receive $12 €$ in a week & Receive $4 €$ today \\
\hline 3 & Receive $12 €$ in a week & Receive $6 €$ today \\
\hline 4 & Receive $12 €$ in a week & Receive $8 €$ today \\
\hline 5 & Receive $12 €$ in a week & Receive $10 €$ today \\
\hline \multicolumn{2}{|c|}{ I choose Plan A for Questions1 until } & I choose Plan B for Questions__ until 5 \\
\hline & Plan A & Plan B \\
\hline 6 & Receive $12 €$ in a month & Receive $2 €$ today \\
\hline 7 & Receive $12 €$ in a month & Receive $4 €$ today \\
\hline 8 & Receive $12 €$ in a month & Receive $6 €$ today \\
\hline 9 & Receive $12 €$ in a month & Receive $8 €$ today \\
\hline 10 & Receive $12 €$ in a month & Receive $10 €$ today \\
\hline \multicolumn{2}{|c|}{ I choose Plan A for Questions 6 until } & I choose Plan B for Questions___ until 10 \\
\hline & Plan A & Plan B \\
\hline 11 & Receive $12 €$ in 3 months & Receive $2 €$ today \\
\hline 12 & Receive $12 €$ in 3 months & Receive $4 €$ today \\
\hline 13 & Receive $12 €$ in 3 months & Receive $6 €$ today \\
\hline 14 & Receive $12 €$ in 3 months & Receive $8 €$ today \\
\hline 15 & Receive $12 €$ in 3 months & Receive $10 €$ today \\
\hline \multicolumn{2}{|c|}{ I choose Plan A for Questions11 until___ } & I choose Plan B for Questions___ until 15 \\
\hline & Plan A & Plan B \\
\hline 16 & Receive $30 €$ in a week & Receive $5 €$ today \\
\hline 17 & Receive $30 €$ in a week & Receive $10 €$ today \\
\hline 18 & Receive $30 €$ in a week & Receive $15 €$ today \\
\hline 19 & Receive $30 €$ in a week & Receive $20 €$ today \\
\hline 20 & Receive $30 €$ in a week & Receive $25 €$ today \\
\hline \multicolumn{2}{|c|}{ I choose Plan A for Questions16 until_ } & I choose Plan B for Questions___ until 20 \\
\hline & Plan A & Plan B \\
\hline 21 & Receive $30 €$ in a month & Receive $5 €$ today \\
\hline 22 & Receive $30 €$ in a month & Receive $10 €$ today \\
\hline 23 & Receive $30 €$ in a month & Receive $15 €$ today \\
\hline 24 & Receive $30 €$ in a month & Receive $20 €$ today \\
\hline 25 & Receive $30 €$ in a month & Receive $25 €$ today \\
\hline \multicolumn{2}{|c|}{ I choose Plan A for Questions 21 until } & I choose Plan B for Questions___ until 25 \\
\hline & Plan A & Plan B \\
\hline 26 & Receive $30 €$ in 3 months & Receive $5 €$ today \\
\hline 27 & Receive $30 €$ in 3 months & Receive $10 €$ today \\
\hline 28 & Receive $30 €$ in 3 months & Receive $15 €$ today \\
\hline 29 & Receive $30 €$ in 3 months & Receive $20 €$ today \\
\hline 30 & Receive $30 €$ in 3 months & Receive $25 €$ today \\
\hline \multicolumn{2}{|c|}{ I choose Plan A for Questions 26 until } & I choose Plan B for Questions___ until 30 \\
\hline
\end{tabular}




\begin{tabular}{|c|c|c|}
\hline & Plan A & Plan B \\
\hline 31 & Receive $3 €$ in a week & Receive 0,5 today \\
\hline 32 & Receive $3 €$ in a week & Receive $1 €$ today \\
\hline 33 & Receive $3 €$ in a week & Receive $1,5 €$ today \\
\hline 34 & Receive $3 €$ in a week & Receive $2 €$ today \\
\hline 35 & Receive $3 €$ in a week & Receive $2,5 €$ today \\
\hline \multicolumn{2}{|r|}{ I choose Plan A for Questions 31 until_ } & I choose Plan B for Questions___ until 35 \\
\hline & Plan A & Plan B \\
\hline 36 & Receive $3 €$ in a month & Receive 0,5 today \\
\hline 37 & Receive $3 €$ in a month & Receive $1 €$ today \\
\hline 38 & Receive $3 €$ in a month & Receive $1,5 €$ today \\
\hline 39 & Receive $3 €$ in a month & Receive $2 €$ today \\
\hline 40 & Receive $3 €$ in a month & Receive $2,5 €$ today \\
\hline \multicolumn{2}{|r|}{ I choose Plan A for Questions 36 until__ } & I choose Plan B for Questions___ until 40 \\
\hline & Plan A & Plan B \\
\hline 41 & Receive $3 €$ in 3 months & Receive 0,5 today \\
\hline 42 & Receive $3 €$ in 3 months & Receive $1 €$ today \\
\hline 43 & Receive $3 €$ in 3 months & Receive $1,5 €$ today \\
\hline 44 & Receive $3 €$ in 3 months & Receive $2 €$ today \\
\hline 45 & Receive $3 €$ in 3 months & Receive $2,5 €$ today \\
\hline \multicolumn{2}{|c|}{ I choose Plan A for Questions 41 until___ } & I choose Plan B for Questions___ until 45 \\
\hline & Plan A & Plan B \\
\hline 46 & Receive $24 €$ in 3 days & Receive $4 €$ today \\
\hline 47 & Receive $24 €$ in 3 days & Receive $8 €$ today \\
\hline 48 & Receive $24 €$ in 3 days & Receive $12 €$ today \\
\hline 49 & Receive $24 €$ in 3 days & Receive $16 €$ today \\
\hline 50 & Receive $24 €$ in 3 days & Receive $20 €$ today \\
\hline \multicolumn{2}{|c|}{ I choose Plan A for Questions 46 until__ } & I choose Plan B for Questions___ until 50 \\
\hline & Plan A & Plan B \\
\hline 51 & Receive $24 €$ in 2 weeks & Receive $4 €$ today \\
\hline 52 & Receive $24 €$ in 2 weeks & Receive $8 €$ today \\
\hline 53 & Receive $24 €$ in 2 weeks & Receive $12 €$ today \\
\hline 54 & Receive $24 €$ in 2 weeks & Receive $16 €$ today \\
\hline 55 & Receive $24 €$ in 2 weeks & Receive $20 €$ today \\
\hline \multicolumn{2}{|c|}{ I choose Plan A for Questions 51 until___ } & I choose Plan B for Questions___ until 55 \\
\hline & Plan A & Plan B \\
\hline 56 & Receive $24 €$ in 2 months & Receive $4 €$ today \\
\hline 57 & Receive $24 €$ in 2 months & Receive $8 €$ today \\
\hline 58 & Receive $24 €$ in 2 months & Receive $12 €$ today \\
\hline 59 & Receive $24 €$ in 2 months & Receive $16 €$ today \\
\hline 60 & Receive $24 €$ in 2 months & Receive $20 €$ today \\
\hline \multicolumn{2}{|c|}{ I choose Plan A for Questions 56 until_ } & I choose Plan B for Questions___ until 60 \\
\hline
\end{tabular}




\begin{tabular}{|c|c|c|}
\hline & Plan A & Plan B \\
\hline 61 & Receive $6 €$ in 3 days & Receive $1 €$ today \\
\hline 62 & Receive $6 €$ in 3 days & Receive $2 €$ today \\
\hline 63 & Receive $6 €$ in 3 days & Receive $3 €$ today \\
\hline 64 & Receive $6 €$ in 3 days & Receive $4 €$ today \\
\hline 65 & Receive $6 €$ in 3 days & Receive $5 €$ today \\
\hline \multicolumn{2}{|c|}{ I choose Plan A for Questions 61 until__ } & I choose Plan B for Questions___ until 65 \\
\hline & Plan A & Plan B \\
\hline 66 & Receive $6 €$ in 2 weeks & Receive $1 €$ today \\
\hline 67 & Receive $6 €$ in 2 weeks & Receive $2 €$ today \\
\hline 68 & Receive $6 €$ in 2 weeks & Receive $3 €$ today \\
\hline 69 & Receive $6 €$ in 2 weeks & Receive $4 €$ today \\
\hline 70 & Receive $6 €$ in 2 weeks & Receive $5 €$ today \\
\hline \multicolumn{2}{|c|}{ I choose Plan A for Questions 66 until__ } & I choose Plan B for Questions___ until 70 \\
\hline & Plan A & Plan B \\
\hline 71 & Receive $6 €$ in 2 months & Receive $1 €$ today \\
\hline 72 & Receive $6 €$ in 2 months & Receive $2 €$ today \\
\hline 73 & Receive $6 €$ in 2 months & Receive $3 €$ today \\
\hline 74 & Receive $6 €$ in 2 months & Receive $4 €$ today \\
\hline 75 & Receive $6 €$ in 2 months & Receive $5 €$ today \\
\hline \multicolumn{2}{|c|}{ I choose Plan A for Questions 71 until_ } & I choose Plan B for Questions___ until 75 \\
\hline
\end{tabular}

